\title{
Victor N. Shaw \\ Peer Review as a Motivating Device in the Training of Writing Skills for College Students
}

This article introduces an innovative method of training in writing skills in content areas for college students. The method involves the use of a peerreview panel to encourage students to write in-class essays in academic and professional formats. The basic features are: Students take the instructor's perspective; they internalize class performance standards; and thus, they voluntarily incorporate those standards in their attitudes toward instruction as well as in their learning behaviors.

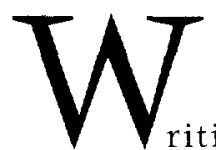

affords students an indispensable tool to record what they have learned and observed, to express what they have experienced in their inner world, and, most importantly, to embark on new projects on the basis of learning (Hayes \& Flower, 1980; Shaw, 1999). Training students with appropriate writing skills is a major task in all levels of education. On college and university campuses, as more and more students come from diverse backgrounds and with inadequate academic preparation, instructors have to explore into and experiment with more and more innovative and effective methods in both content course teaching and basic skill training (Creigh, 1977/8; Demicell, 1979; Dobie, 1993; Haas \& Smoke, 1990; Hendriks \&

Victor Shaw is currently teaching sociology and criminology at California State University-Northridge. Dr. Shaw is interested in the study of deviance, crime, social control, organizational behavior, public policy and pedagogy. He has published widely in those areas. Please address correspondence to: Dr. Victor N. Shaw, 3140 Anasazi Way, Simi Valley, CA 93063. Telephone and Facsimile: 805-584-8683. Email: victor.shaw@csun.edu. 
Quinn, 2000; McNaughton, Hughes, \& Clark, 1997; Shaw, 2002). Although styles of learning that arise from general education naturally make their way to specific student groups, modes of teaching that emerge from special education, such as areas of learning assistance and developmental education, may find their appeals and applications in larger student populations as well (Avinger, Hatcher, Fischer, \& O'Rear, 1998; Burkhalter, 2000; Chand, 1985; Livingston, 1996; McAndrew \& Williamson, 1985; Mullin, 1998; Schiff, 1980).

\section{Background}

In my classes, I train students in writing skills through a wide variety of writing exercises, including in-class question-answering essays, weekly journals, conference abstracts, journal article summaries, news item analyses, book reviews, theme topic essays, research project reports, and analytical term papers.

For each writing project, I first provide students with clear directions for content and structure. For example, directions for a news item analysis instruct students to (a) identify a news report related to a predesignated theme topic in a national newspaper; (b) analyze that report using concepts or theories learned from the class; and (c) propose a new approach, different from the journalist approach critiqued in the analysis, to the key issue touched upon by the news re port. Second, I allow students to search the literature for publications by the instructor. Published work by the instructor serves students not only as an explicit model, but also as a powerful source of inspiration for their exercise in academic and professional writings. Third, in small graduate seminars, I ask students to write presentation proposals. I then work one on one with them to rewrite their drafts and submit their final proposals for presentation consideration in formal academic conferences. Students are amazed to see how their originel drafts can be drastically changed to fit into the standard format of acaclemic writings. Finally, I encourage students in all classes to start their writing assignments early enough in the semester so that they have a draft to solicit comments from the instructor as well as from their friends, colleagues, former teachers, and significant others.

Despite these diverse efforts, few students closely follow the instructor's guidance, actively seek advice from the instructor, or in the end turn in a quality writing product. In fact, the majority tend to write their papers in the last several days of the semester; they are reluctant to show their papers to anyone; and they hand in their writing assignments to face whatever consequence they create for themselves. 


\section{Rationale}

According to my observation, students take a "bet-on-fate" approach toward writing assignments because writing assignments are usually required as one-time hand-ins. Because there is a lack of routine practice on and hence a general fear of writing, many students wait until they feel forced to do it by the pressure of a deadline. As they rush through writing and know they have produced something substandard to present, they hold onto it until they have to hand it in to the instructor at the end of the semester. They do not care if they show a poorly written product to the instructor, not only because they have to face the instructor one way or the other, but also because they think the instructor already knows how "awful" or "awesome" they are in class performance.

Given student reactions toward conventional writing assignments, can something be done for a positive change? Does it make a difference if students are not just given one-time writing assignments but involved in an on-going process of practice? Does it help if students are not just allowed to hand in their writing product to the instructor but required to submit it for open evaluation and critique by fellow participants in class? How about if students are not just given written directions on a writing assignment but offered actual writing samples to see exactly how a topic-specific essay is supposed to be written in terms of content and form (Englert \& Raphael, 1988; Issacson, 1994)?

\section{Procedure}

To translate ideas into practice, I have experimented with a writing exercise procedure that I call "meet the standards because I know them" in specific upper division courses, including culture and society, ethics, and classical sociological theory. Because each of the selected courses is a challenging required upper-division course, many students do not take it until they have naturally accumulated adequate reading and writing skills through work in other courses.

A class normally includes 30 students. It meets 75 minutes every Tuesday and Thursday for 15 weeks in a semester. The course content is divided into five major units. The students have three weeks to work on course materials in each unit. In any typical three-week period, I lecture on specific course content in the first class meeting of each week. In the second class meeting of the first two weeks, three students make presentations on course materials scheduled for the period, followed by group or class-wide discussion. Presentations are evaluated by the rest of the class for content, organization, clarity, style, manner, and overall performance. In the second class meeting of the third week, 
the class takes an in-class essay exam on subject matter covered in the unit.

Each exam is composed of six essay questions. Detailed directions are given in the beginning so that students know clearly how much attention they have to pay to content, logical reasoning, organization, and style. While the majority of the class is working on the exam, the six students who have presented on course materials in the period convene in a separate room to schedule meetings and discuss guidelines for grading written essays by their fe:llow class participants. The student evaluators are provided with origiral questions, detailed exam-taking directions, standard essay answers, and specific grading requirements by the instructor.

The six-student judge panel has one week to read, grade, and write necessary comments on all essay exams. The evaluators may meet once for a few hours or several times in the week to finish their job. In the evaluation process, they may adopt business procedures or develop some division of labor to facilitate their task performance. But to ensure a full review of and a balanced decision on each exam, all student judges are required to read each essiay by each of their classmates and contribute their respective input toward the final consensus. The instructor may sit in panel meetings to offer advice or troubleshoot problems. But to allow for indeperdent judgment by students, I just stay in my office when they work on their evaluations in a separate room. I step in only when I am called for direction or assistance.

\section{Schedule of Activities}

\begin{tabular}{|c|c|c|c|c|}
\hline \multirow[t]{6}{*}{ Unit 1} & Week 1 & Day 1 & Instructor's lecture & Chapter 1 \\
\hline & & Day 2 & Three student presentations and class discussion & Chapter 1 \\
\hline & Week 2 & Day 1 & Instructor's lecture & Chapter 2 \\
\hline & & Day 2 & Three student presentaticns and class discussion & Chapter 2 \\
\hline & Week 3 & Day 1 & Instructor's lecture & Chapter 3 \\
\hline & & Day 2 & $\begin{array}{l}\text { Essay Exam 1, Six presenting students in Unit } 1 \\
\text { do not take but work in a panel to grade Exam } 1\end{array}$ & Chapter $1,2, \& 3$ \\
\hline \multirow[t]{6}{*}{ Unit 2} & Week 1 & Day 1 & Instructor's lecture & Chapter 4 \\
\hline & & Day 2 & $\begin{array}{l}\text { Three student presentations and class discussion } \\
\text { Six student judges from Unit } 1 \text { discuss Exam } 1\end{array}$ & Chapter 4 \\
\hline & Week 2 & Day 1 & Instructor's lecture & Chapter 5 \\
\hline & & Day 2 & $\begin{array}{l}\text { Three student presentations and class discussion } \\
\text { Six student judges submit final grades for Exam } 1\end{array}$ & Chapter 5 \\
\hline & Week 3 & Day 1 & Instructor's Lecture & Chapter 6 \\
\hline & & Day 2 & $\begin{array}{l}\text { Essay Exam 2, Six presenting students in Unit } 2 \\
\text { do not take but work in a panel to grade Exam } 2\end{array}$ & Chapter $4,5, \& 6$ \\
\hline
\end{tabular}

Unit 3 Week 1 Day 1 Continues ... 
After they finish grading all the essays, student evaluators turn the essays back to their peers. As a panel, they sit in front of the class first to explain what standard essay answers they received from the instructor, what procedure they adopted in their evaluation, and how they reached consensus on their final decisions. They then take questions from the class regarding answers in each essay. For specific disputes, they make appointments to work with concerned students in separate meetings. A leader usually emerges in the process. He or she may answer more questions than other panel members. But all six members of the panel are required to be present in both class-wide meetings and face-to-face sessions with individual complainants.

The general class-wide discussion on grading takes place in the second meeting of the week following the exam. It uses part of the postpresentation discussion time scheduled for the week. The student judge panel submits to the instructor final grades when it has resolved all specific disputes, no later than two weeks after the exam date. Student judges do not take the exam by themselves, so they each receive the average score they grade on the class for the exam.

\section{Student Reaction}

Compared to classes of the same course when the instructor takes grading in his own hands, the class following the procedure spends more time working on the exam. Participants write longer and better essays. The contrast is relatively small in the first exam when the class is not so clear about how the procedure works throughout the semester. But after the first exam, the first panel evaluation, and the first classwide discussion of grading, the class attitudes and behaviors toward the essay exam change dramatically. Students request extra time to finish their writing, express how much more they want to include in their essay, and show their pinched red hand after intensive writing.

Specifically, the instructor has observed three major changes in student reactions. First, because student judges gain access to the instructor's essay answers and discuss student responses in a variety of contexts, the class becomes better informed of expectations regarding the essay content, organization, and style. Second, students seem to care about how their works appear to classmates. In class-wide discussion of grading, some student panelists say directly to the class: "Some of you guys write really bad." Peer pressure stimulates students to compete with each other in positive ways. Most essentially, it eliminates the expectation gap students tend to keep from their instructor. When essays are reviewed by the instructor, whom students perceive to be more knowledgeable and capable than themselves, they 
seem to assume: "I am his or her student. He or she does not expect me to turn in a masterpiece. He or she already knows how good or bad I am in writing. I then can just do wh.at I feel comfortable to do in front of him or her." However, when exams are evaluated by classmate judges, whom students perceive to be equally knowledgeable and capable as themselves, they seem to reason: "I am their fellow participant in class. They may think me as good as or not so good as themselves. So I have to do the best I can in the eyes of my classmates." Third, as students have the opportunity to be exempt from one exam, they feel a sense of relief and rejuvenation to concentrate on the majority of exams they are required to take with the class. Some students say: "It is really nice to get a break from all these tough exams"; and "I have put all my energy into it. I am not taking the next one!"

Oral and written comments indicate many students are amazed at the creative and innovative nature of the procedure. Some students ask the instructor from where he borrows the method. They seem surprised when they are told it springs right from the mind of the instructor and it is practiced for the first time in their class. Some representative remarks include: "It really helps when I read for myself how the instructor writes for each essay question in the standard answer sheet"; "I am quite surprised when l. see the tremendous differences that exist among our class in writing"; and "I feel a little nervous when I know someone who sits next to me is going to read what I write."

\section{Pedagogical Significance}

In the procedure, students follow the model answer essays written by the instructor and apply whatever standards inherent in those answer essays to evaluate their classmates and guide themselves. By reading and studying answer essays written by the instructor, students become familiar with writing requirements as they are explicitly embodied in the samples. By referring to answer essays in evaluation, students get to know academic judgment as it is made on various individual cases. Instruction and learning therefore become open, equal, and reciprocal for both the instructor and students. The instructor assumes the role of student in working on answering essays. Instead of imposing academic standards upon student;, he or she exemplifies those standards by actually writing sample answers. Instead of preaching to students, he or she learns from class to class in curriculum reform and instructional improvement. Over years of practice, the instructor gathers comments from student judges. He or she incorporates student inputs into his or her essay answers, making them more thorough or complete in terms of academic standards and more sensitive or 
reasonable in accordance with student needs. Students, on the other hand, take the role of instructor. They apply standards and make judgments on academic performance by their classmates and ultimately by themselves. Through the procedure, students not only become identified with academic standards, but also gain a sense of where they are and how to close the gap between requirements and their own performance (Brophy \& Good, 1986; Browne, 1997; Harris $\&$ Graham, 1996).

Another significant aspect of the procedure is the use of peer pressure in the instructional process. Peer pressure is a well-observed social phenomenon (Janis, 1982). How to apply peer pressure to motivate students in their learning itself is a challenging pedagogical issue (Amores, 1997; Boyle, 1996; Mazur, 1997; Moser, 1993; Ransdell, 2001). This procedure, however, demonstrates that students themselves are most original and powerful resources for both learning and instruction. Instructors always need to embrace students in their quest for innovative and effective teaching methods.

\section{Concluding Remarks}

Four obvious questions arise regarding the new procedure. Does it lead to serious erosion of instructional authority? Are academic standards compromised when they are applied by students to themselves? Are students unfairly exploited of their time and energy by the procedure? And is the instructor willing to accept the extra burden of monitoring students and running all necessary chores through the procedure? In my observation and experience, students show more understanding and respect for the instruction and instructor when they are entrusted to exercise part of the instructional judgment in their own learning. They are eager to demonstrate that they are fair, professional, compassionate, and adhere to the highest standards when they are given the opportunity to evaluate fellow participants. No obvious trace of score inflation appears from panel to panel and from class to class in spite of the fact that the student judges earn the average score of the exams they grade. Finally, because the procedure motivates students to learn and helps the instructor to teach, both students and the instructor feel they have made the best use of their time and energy.

In the larger educational context, the procedure demystifies the instructional process so that students know how academic standards are created, applied, and modified. Second, it equalizes the instructor with students so that the instructor knows how he or she would do as a capable student and students know how they make decisions using their scholarly conscience and professional judgment. Third, it gives 
students an opportunity to review, understand, and internalize academic standards. Fourth, as students become identified with academic standards, they voluntarily follow those standards to shape their attitude and guide their behavior in learning. Lastly, the procedure creates an interactive network among students so that they monitor, compete with, and learn from each other as a class. Learning therefore becomes an active, collaborative, and participatory process for all students: they review and write critical essays; they create and apply rules and standards; and they judge and are judged on their own academic performance.

All these positive features make the procedure worthy enough of an attempt in practice. Beyond practical benefits, the new method engages students as both starting and ending points, both carriers and implementers, and both sources and resources in learning, teaching, and general educational innovations.

\section{References}

Amores, M. J. (1997). A new perspective on peer editing. Foreign Language Annals, 30 (4), 513-522.

Avinger, C., Hatcher, R., Fischer, C. K., \& O Rear, K. (1998). Ideas in practice: Writing centers for the 21 st century. Journal of Developmental Education, 21 (3), 26-28,30,32.

Boyle, C. (1996). Efficacy of peer evaluation and effects of peer evaluation on argumentative writing. Unpublished master's thesis, San Diego State University, San Diego, CA.

Brophy, J., \& Good, T. L. (1986). Teacher behavior and student achievement. In M. C. Wittrock (Ed.), Handbook of research on teashing (pp. 328-375). New York: Macmillan. Browne, M. N. (1997). Striving for excellence in college: Tips for active learning. Upper Saddle River, NJ: Prentice Hall.

Burkhalter, B. (2000). Pathways to success: Firidging the gap between high school and college composition. Research \&s Teaching in Developmental Education, 16 (2), 113-117.

Chand, S. (1985). The impact of developmertal education at Triton College. Journal of Developmental Education, 9 (1), 2-5.

Creigh, J. (1977/8). Stepping through the open door: The underprepared student and his problems. English Quarterly, 10 (4), 37-44.

Demicell, J. A. (1979). The problem of student diversity in community colleges. English Quarterly, 12 (3), 69-71.

Dobie, A. B. (1993). Older students, younger classmates, and their writing instructors. Research and Teaching in Developmental Education, 10 (1), 5-29.

Englert, C. S., \& Raphael, T. E. (1988). Constructing well-formed prose: Process, structure, and metacognitive knowledge. Exceptional Children, 54, 513-520.

Haas, T., \& Smoke, T. (1990). Talking to learn: Conversation workshops for ESL students. Journal of Developmental Education, 14 (2), 14-16,18. 
Harris, K. R., \& Graham, S. (1996). Making the writing process work: Strategies for composition and self-regulation. Cambridge, MA: Brookline Books.

Hayes, J. R., \& Flower, L. S. (1980). Identifying the organization of writing processes. In L. W. Gregg \& E. R. Steinberg (Eds.), Cognitive process in writing (pp. 3-30). Hillsdale, NJ: Erlbaum.

Hendricks, M., \& Quinn, L. (2000). Teaching referencing as an introduction to epistemological empowerment. Teaching in Higher Education, 5 (4): 447-457.

Issacson, S. (1994). Integrating process, product, and purpose: The role of instruction. Reading and Writing Quarterly, 10, 39-62.

Janis, I. (1982). Groupthink: Psychological studies of policy decisions and fiascoes. Boston: Houghton Mifflin.

Livingston, S. (1996). Promising practice: Teaching developmental writing to postsecondary students who are deaf. Journal of Postsecondary Education and Disability. $12(2), 43-44$.

Mazur, E. (1997). Peer instruction. Upper Saddle River, NJ: Prentice Hall.

McAndrew, D., \& Williamson, M. (1985). Research on writing III: Teaching the basic writer. Research \& Teaching in Developmental Education, 2 (1), 48-56.

McNaughton, D., Hughes, C., \& Clark, K. (1997). The effect of five proofreading conditions on the spelling performance of college students with learning disabilities. Journal of Learning Disabilities, 30 (6), 643-651.

Moser, J. (1993). Crossed currents: ESL students and their peer tutors. Research and Training in Developmental Education, 9 (2), 37-43.

Mullin, A. E. (1998). Another look at student writing and stages of intellectual development. Journal of College Reading and Learning, 28 (2), 79-92.

Ransdell, D. R. (2001). Class workshops: An alternative to peer-group review. Teaching English in the Two-Year College, 29 (1), 32-43.

Schiff, P. M. (1980). Ideas in practice. ... Or not using prose models. Journal of Developmental \& Remedial Education, 4 (1), 25-26.

Shaw, V. N. (1999). Reading, presentation, and writing skills in content courses. College Teaching, 47(4), 153-157.

Shaw, V. N. (2002). Essential social sciences skills in college and university education. Contemporary Education, 72 (1), 39-43. 